\begin{tabular}{|c|c|c|c|c|c|}
\hline & $\begin{array}{l}\text { At EULAR/ACR } \\
\text { classification, \% }\end{array}$ & $\begin{array}{c}\text { EULAR/ACR met at } \\
\text { the same time, \% }\end{array}$ & $\begin{array}{l}\text { EULAR/ACR met } \\
\text { earlier, \% }\end{array}$ & $\begin{array}{l}\text { EULAR/ACR met } \\
\text { later, \% }\end{array}$ & $p$ value* \\
\hline ACR/EULAR criteria & $n=558$ & $n=344$ & $n=41$ & $n=173$ & \\
\hline \multicolumn{6}{|l|}{ CLINICAL } \\
\hline Oral ulcers & 30.7 & 25.3 & 0.0 & 48.6 & $<0.0001$ \\
\hline Discoid rash & 9.7 & 8.1 & 0.0 & 15.0 & 0.0027 \\
\hline Malar rash & 45.3 & 38.1 & 14.6 & 67.1 & $<0.0001$ \\
\hline Arthritis & 66.1 & 68.3 & 14.6 & 74.0 & $<0.0001$ \\
\hline Psychosis & 3.1 & 3.2 & 0.0 & 3.5 & 0.7848 \\
\hline Seizures & 5.0 & 6.4 & 2.4 & 2.9 & 0.1821 \\
\hline Pleurisy & 35.8 & 38.7 & 22.0 & 33.5 & 0.0817 \\
\hline Leukopenia & 40.5 & 40.7 & 19.5 & 45.1 & 0.0093 \\
\hline Thrombocytopenia & 12.9 & 14.2 & 12.2 & 10.4 & 0.4736 \\
\hline Autoimmune hemolysis & 7.9 & 7.0 & 19.5 & 6.9 & 0.0307 \\
\hline Proteinuria & 23.5 & 26.5 & 31.7 & 15.6 & 0.0080 \\
\hline Renal biopsy II or V & 8.2 & 8.1 & 26.8 & 4.0 & 0.0001 \\
\hline Renal biopsy III or IV & 4.7 & 4.1 & 9.8 & 4.6 & 0.2405 \\
\hline \multicolumn{6}{|l|}{ IMMUNOLOGIC } \\
\hline $\mathrm{aCL}>40$ & 16.9 & 15.4 & 12.2 & 20.8 & 0.2411 \\
\hline Anti-Smith & 30.3 & 35.8 & 26.8 & 20.2 & 0.0010 \\
\hline Anti-dsDNA & 52.1 & 58.4 & 53.7 & 39.3 & 0.0002 \\
\hline \multicolumn{6}{|c|}{ *By Chi square and Fisher's exact as appropriate } \\
\hline & $\begin{array}{l}\text { At EULAR/ACR } \\
\text { classification, \% }\end{array}$ & $\begin{array}{c}\text { EULAR/ACR met at } \\
\text { the same time, \% }\end{array}$ & $\begin{array}{l}\text { EULAR/ACR met } \\
\text { earlier, } \%\end{array}$ & $\begin{array}{l}\text { EULAR/ACR met } \\
\text { later, \% }\end{array}$ & p value* \\
\hline \multicolumn{6}{|l|}{ ACR/EULAR criteria } \\
\hline CLINICAL & & & & & \\
\hline Fever & 64.6 & 64.4 & 59.2 & 66.3 & 0.515 \\
\hline Oral ulcers & 45.4 & 41.6 & 36.6 & 53.8 & 0.001 \\
\hline Alopecia & 64.9 & 65.7 & 60.6 & 64.4 & 0.687 \\
\hline Subacute cutaneous lupus & 4.3 & 5.0 & 2.8 & 3.3 & 0.397 \\
\hline Discoid lupus & 11.2 & 10.6 & 1.4 & 14.3 & 0.006 \\
\hline Acute cutaneous & 69.0 & 65.5 & 54.9 & 78.1 & $<0.0001$ \\
\hline Synovitis & 84.6 & 83.1 & 78.9 & 88.5 & 0.039 \\
\hline Psychosis & 7.6 & 6.7 & 9.9 & 8.8 & 0.386 \\
\hline Seizures & 10.3 & 10.1 & 8.5 & 10.9 & 0.802 \\
\hline Pleural or pericardial effusion & 31.4 & 30.9 & 26.8 & 33.1 & 0.543 \\
\hline Pericarditis & 16.6 & 16.6 & 16.9 & 16.7 & 0.996 \\
\hline Leucopenia & 56.7 & 55.8 & 53.5 & 59.0 & 0.554 \\
\hline Thrombocytopenia & 24.3 & 24.1 & 25.4 & 24.3 & 0.973 \\
\hline Autoimmune hemolysis & 13.6 & 16.7 & 7.0 & 9.7 & 0.003 \\
\hline Proteinuria & 48.3 & 47.5 & 50.7 & 49.2 & 0.807 \\
\hline Renal biopsy II or V & 7.6 & 6.5 & 8.5 & 9.4 & 0.270 \\
\hline Renal biopsy III or IV & 19.1 & 19.2 & 21.1 & 18.5 & 0.876 \\
\hline \multicolumn{6}{|l|}{ IMMUNOLOGIC } \\
\hline $\begin{array}{l}\text { aCL IgG }>40 \text { GPL or or anti- } \\
\text { B2 microglobulin }>40 \text { or LAC }\end{array}$ & 38.7 & 38.0 & 39.4 & 39.8 & 0.852 \\
\hline $\mathrm{C} 3$ or $\mathrm{C} 4$ & 59.0 & 59.5 & 64.8 & 56.8 & 0.431 \\
\hline $\mathrm{C} 3$ and $\mathrm{C} 4$ & 44.4 & 46.2 & 46.5 & 40.7 & 0.263 \\
\hline Anti-Smith & 26.3 & 26.4 & 22.5 & 26.8 & 0.756 \\
\hline Anti-dsDNA & 67.6 & 68.7 & 77.5 & 63.5 & 0.051 \\
\hline
\end{tabular}

earlier had a lower frequency of milder manifestations (like mucocutaneous and articular) and tend to have a higher frequency of anti-dsDNA antibodies, suggesting these criteria could be more useful in subsets of patients with more severe disease.

Funding Source(s): None

\section{DEVELOPMENT AND FIRST-IN-HUMAN CHARACTERIZATION OF AN ICOSL AND BAFF BISPECIFIC INHIBITOR AMG 570 FOR SLE TREATMENT}

${ }^{1}$ Laurence E Cheng ${ }^{*},{ }^{1}$ Hailing Hsu, ${ }^{2}$ Martin Kankam, ${ }^{3}$ Nicholas Siebers, ${ }^{3}$ Randall Stoltz, ${ }^{1}$ Lubna Abuqayyas, 'Bella Ertik, 'Barbara Sullivan, 'Lei Zhou, 'Jane R Parnes. 'Amgen Inc;

${ }^{2}$ Vince and Associates Clinical Research; ${ }^{3}$ Covance
Background Autoimmune diseases, including systemic lupus erythematosus (SLE), are associated with dysregulated $\mathrm{T}$ cell and B cell responses. AMG 570 is a bispecific molecule targeting $\mathrm{T}$ cell and $\mathrm{B}$ cell activity through inhibition of inducible costimulator ligand (ICOSL) and $\mathrm{B}$ cell activating factor (BAFF). We hypothesize that targeting both ICOSL and BAFF will be more effective than single target inhibition in SLE and other autoimmune diseases. We investigated if targeting ICOSL and BAFF has superior efficacy to single target inhibition in mouse arthritis and lupus models. We also investigated the safety, tolerability, pharmacokinetics, and pharmacodynamics of AMG 570 in healthy subjects after single subcutaneous doses.

Methods A murine surrogate ICOSL/BAFF bispecific along with single or combination inhibition was evaluated in the mouse collagen-induced arthritis (CIA) and NZB/NZW lupus 
models. AMG 570 binding affinity to human and cyno ICOSL/BAFF was tested by Kinexa A. An ongoing, first-inhuman study has enrolled healthy adult subjects into 6 escalating single-dose cohorts. Eight participants were enrolled into each cohort and randomized 3:1 to receive AMG 570 or placebo. The primary endpoint was treatment-emergent adverse events (AEs). Secondary endpoints included pharmacokinetics and pharmacodynamics.

Results ICOSL and BAFF dual inhibition was more effective than single inhibition in ameliorating arthritis incidence and severity in the mouse CIA model as well as reducing antidsDNA IgG, delaying proteinuria and improving survival in the NZB/NZW lupus model. Based on high affinity to ICOSL and BAFF, AMG 570 was selected for investigation in a single ascending dose study in healthy subjects. As of an ad hoc interim analysis following six cohorts, 48 healthy participants received one dose of investigational product (AMG 570 or placebo). Overall, 73 mild to moderate AEs were reported. The most common AEs were upper respiratory tract infection and injection site erythema. No drug-related serious AEs or fatal AEs were reported thus far. AMG 570 demonstrated nonlinear pharmacokinetics consistent with cell surface ICOSL binding. At the highest dose tested, AMG 570 achieved $>90 \%$ mean ICOSL receptor occupancy on circulating $\mathrm{B}$ cells 8 days after dosing. AMG 570 led to a reduction in circulating naïve $B$ cells and an increase in circulating memory B cells.

Conclusions Dual inhibition of ICOSL and BAFF is more efficacious than single target inhibition in mouse disease models. In healthy subjects to date, single doses of AMG 570 have been safe, well tolerated, and demonstrated pharmacodynamic activity consistent with inhibition of both ICOSL and BAFF. Funding Source(s): Amgen Inc.

\section{ASSESSMENT OF THE QRISK2, QRISK3, SLE CARDIOVASCULAR RISK EQUATION, MODIFIED FRAMINGHAM AND FRAMINGHAM RISK CALCULATORS AS PREDICTORS OF CARDIOVASCULAR DISEASE EVENTS IN SYSTEMIC LUPUS ERYTHEMATOSUS}

${ }^{1}$ Jagan Sivakumaran*, ${ }^{2}$ Paula Harvey, ${ }^{1}$ Ahmed Omar, ${ }^{3}$ Murray B Urowitz, ${ }^{3}$ Dafna D Gladman, ${ }^{4}$ Nicole Anderson, ${ }^{4}$ Jiandong Su, ${ }^{3}$ Zahi Touma. ${ }^{1}$ University of Toronto; ${ }^{2}$ Division of Cardiology, Women's College Hospital; ${ }^{3}$ Krembil Research Institute, University of Toronto; ${ }^{4}$ The Centre for Prognosis Studies in the Rheumatic Diseases Toronto Western Hospital

\subsection{6/lupus-2019-Ism.291}

Background Systemic lupus erythematosus (SLE) is recognised as an independent risk factor for cardiovascular disease (CVD). This study aimed to determine which cardiovascular risk assessment tool: QRISK2, QRISK3, Framingham (FRS), Modified FRS (mFRS) or SLE Cardiovascular Risk Equation (SLECRE) best predicts CVD in SLE. QRISK3, mFRS and SLECRE are CVD risk assessment instruments considering SLE in risk prognosticating patients.

Methods Single-centre analyses on prospectively collected data of 1887 SLE patients were performed to compute 10 year CVD risk scores for each tool. Tools scores were evaluated against CVD development at or within ten years for cases (CVD events) and controls (no CVD events). For cases, the index date for risk score calculation was chosen 10 years, or as close to 10 years as possible prior to the CVD event. Similarly, for controls, risk scores were calculated as close to 10 years as possible prior to the most recent clinic appointment. Proportions of patients classified as low risk $(<10 \%)$, median risk $(10 \%-20 \%)$ and high risk $(>20 \%)$ of developing CVD according to each tool were determined. Sensitivity, specificity, positive/negative predictive values and c-statistics of these tools were analysed.

Results 232 total CVD events were seen in the cohort including myocardial infarction, stroke, transient ischemic attack, heart failure and CVD death. QRISK2 and FRS performances were similar, while the QRISK3 and mFRS performances were similar. The SLECRE classified the highest number of patients

Abstract 291 Table 1 Percentage of cases and controls classified as low $(<10 \%)$, median (10-20\%) and high risk of developing CVD according to each CVD risk assessment tool

\begin{tabular}{|c|c|c|c|c|}
\hline Tool & CVD Status & $\begin{array}{c}\text { Low Risk } \\
(<\mathbf{1 0} \mathbf{( \% )})\end{array}$ & $\begin{array}{c}\text { Median Risk } \\
(\mathbf{1 0}-\mathbf{2 0} \mathbf{)}) \mathbf{( \% )}\end{array}$ & $\begin{array}{c}\text { High Risk } \\
(\mathbf{> 2 0} \mathbf{)}) \mathbf{( \% )}\end{array}$ \\
\hline \multirow{2}{*}{ QRISK2 } & Cases & 81 & 14 & 4 \\
\hline \multirow{2}{*}{ FRS } & Controls & 93 & 5 & 2 \\
\hline \multirow{2}{*}{ QRISK3 } & Cases & 78 & 16 & 6 \\
\hline \multirow{2}{*}{ mFRS } & Controls & 93 & 6 & 1 \\
\hline & Cases & 53 & 27 & 20 \\
\hline \multirow{2}{*}{ SLECRE } & Controls & 78 & 13 & 9 \\
\hline & Cases & 54 & 25 & 21 \\
\hline & Controls & 83 & 10 & 7 \\
\hline
\end{tabular}

